\title{
Diochus cleidecostae, a new species from the Brazilian Amazon and a discussion of the sexual dimorphism on sternum VIII (Coleoptera: Staphylinidae: Staphylininae: Diochini)
}

\author{
Edilson Caron ${ }^{1,3}$; Bruna V. Navarro ${ }^{1,4}$ \& Reinaldo L. Cajaiba ${ }^{2,5}$ \\ 1 Universidade Federal do Paraná (UFPR), Departamento de Biodiversidade (DBD). Palotina, PR, Brasil. \\ 2 Instituto Federal de Educação, Ciência e Tecnologia do Maranhão (IFMA). Buriticupu, MA, Brasil. \\ ${ }^{3}$ ORCID: http://orcid.org/0000-0001-7136-2218. E-mail: caron@ufpr.br (corresponding author) \\ ${ }^{4}$ ORCID: http://orcid.org/0000-0003-3811-3521. E-mail: brunaviananavarro@gmail.com \\ ${ }^{5}$ ORCID: http://orcid.org/0000-0003-0176-9201. E-mail: reinaldocajaiba@hotmail.com
}

\begin{abstract}
Diochus Erichson is a worldwide rove beetle genus with species found in forest floor litter. Three species of Diochus were recently collected in northern Brazil, one of them considered as new and herein described. Within Diochus nanus-group, D. cleidecostae sp. nov. differs from D. apicipennis Cameron, D. nanus Erichson and D. perplexus Cameron by the aedeagus with clearing trifurcate apex of parameres; and differs from $D$. parvulus Kraatz by the three apical long setae of parameres distributed on ventral and dorsal lobes. A previous key to the $D$. nanus-group is updated to include the new species. Here we also report for the first time D. santacatarinae Irmler and D. parvulus from Pará state, Brazil. Finally, a discussion about the sexual dimorphism on sternum VIII is also provided for the genus.
\end{abstract}

Key-Words. Amazon; Morphology; Neotropical; Rove beetles; Taxonomy.

\section{INTRODUCTION}

The tribe Diochini Casey includes the worldwide genus Diochus Erichson and the Chilean and Argentinian genus Antarctothius Coiffait \& Saiz. The Vietnamese genus Coomania Cameron was recently removed from Diochini and now is assigned to Coomaniinae Zyla \& Solodovnikov (Zyla \& Solodovnikov, 2019). Here we adopt Diochini as tribe of Staphylininae following Cai et al. (2019), and not as tribe of Xantholininae, as suggested by Zyla \& Solodovnikov (2019). In both above mentioned studies, Diochini is a sister-group of (Othiini (Maorothiini, Xantholinini).

The species of Diochus are found in forest floor litter and they are easily identified by the minute and aciculate apical maxillary palpomere, and the neck, which is nearly one-third the width of the head. A detailed diagnosis for the genus was provided by Smetana (1982) and Zhou \& Zhou (2016). Diochus includes 78 extant species and one fossil (Chatzimanolis \& Engel, 2011; Newton, 2019). Recently, Irmler (2017) revised the Neotropical species of Diochus and allocated the 37 species in six species-groups. One of them, the Diochus nanus-group, includes four species, which share body with light colouration (yellow to light brown), antennomeres 4-10 wider than long, aedeagus with parameres widened at apex forming a large plate or with two or three lobes, and each paramere with three apical long setae (Irmler, 2017). Another group is the D. verhaaghi-group, with two species that share body brown (darker than $D$. nanus-group), aedeagus with parameres slightly widened at apex, not bifurcate, and each paramere with four apical setae (Irmler, 2017). Among the specimens studied by Cajaiba et al. (2017) we identified three species of Diochus belonging to the two species groups discussed above (two in $D$. nanus-group and one in D. verhaaghi-group). One of the species in $D$. nanusgroup is considered as new and herein described. The key for D. nanus-group from Irmler (2017) is updated to include the new species. Here we also report for the first time $D$. santacatarinae Irmler and $D$. parvulus Kraatz from Pará state. Finally, a discussion about the sexual dimorphism on sternum VIII is also provided for the genus. 


\section{MATERIAL AND METHODS}

The specimens were collected in the municipality of Uruará, state of Pará, in areas of primary forest, secondary forest with 15 years of regeneration, secondary forest with five years of regeneration, agriculture (cocoa plantations, Theobroma cacao L.), and pasture for extensive livestock (Figs. 1-3). The material is deposited in "Coleção Entomológica Pe. Jesus Santiago Moure", Departamento de Zoologia, Universidade Federal do Paraná, Curitiba, Brazil (DZUP) and in the Museu de Zoologia da Universidade de São Paulo, São Paulo, Brazil (MZSP). Dried specimens were immersed in $10 \%$ potassium hydroxide overnight (about 12-15 hours), followed by a bath of acetic acid to neutralize the hydroxide and then water to remove any residue. Dissections were performed under a stereoscopic microscope, and the habitus photographs and dissected parts were illustrated using a light or stereoscopic microscope. The additional measurements follow Irmler (2017): eye length (EL), head length ( $H L)$, relative length of eyes as EL : HL ratio, width of head at posterior angles of head (PW), width of head at anterior edge of eyes (EW), and the divergence of head abbreviated as PW : EW ratio. The dissected parts were placed inside micro vials with glycerin and pinned with the respective specimens. Label information is listed in sequence from top to bottom. The data from each label are enclosed within double quotes (" "), a forward slash (/) separates lines, and information enclosed by square brackets ([ ]) provides additional details. The terminology follows Irmler (2017).

\section{RESULTS}

Twelve species of Diochus belonging to the five species groups are recorded from the Brazilian Amazon (Table 1), two of which are therein recorded for the first time: $D$. santacatarinae Irmler, belonging to the $D$. verhaaghi-group (species group recorded for the first time from the Brazilian Amazon), and D. parvulus Kraatz (species for the first time recorded from the state of Pará) and D. cleidecostae Caron \& Navarro sp. nov.

\section{Diochus santacatarinae Irmler, 2017 (Figs. 4, 7-9, 18-19)}

Diochus santacatarinae Irmler, 2017: 34 (original description, type locality: "Brazil: Santa Catarina").

Holotype (not seen) deposited in Senckenberg Deutsches Entomologisches Institut, Müncheberg, Germany (SDEI) (Irmler, 2017).

Material examined: "Brasil, Pará, Uruará / Cap5 [secondary vegetation with five years of regeneration], VI-2015, / Intermediário [collection information], Serrapilheira [Forest litter] / Reinaldo, Wully, Sidi, col." [white label, printed in black] (6 ơ dissected, 4 \% dissected, DZUP). "Brasil, Pará, Uruará / Cap15 [secondary vegetation with 15 years
Table 1. Diochus species groups and valid species recorded from the Brazilian Amazon.

\begin{tabular}{cc}
\hline Diochus inornatus-group & Diochus Iongicornis-group \\
D. amazonensis Irmler, 2017 & D. Iongicornis Sharp, 1876 \\
D. hanagarthi Irmler, 2017 & D. tarsalis Sharp, 1876 \\
D. inornatus Sharp, 1885 & \\
D. novus Irmler, 2017 & Diochus maculicollis-group \\
D. tricolor Irmler, 2017 & D. peruvianus Irmler, 2017 \\
D. vicinus Sharp, 1876 & \\
Diochus verhaaghi-group & Diochus nanus-group \\
D. santacatarinae Irmler, 2017 & D. cleidecostae Caron \& Navarro sp. nov. \\
\hline
\end{tabular}

of regeneration], VI-2015, / Intermediário[collection information], / Serrapilheira [Forest litter] / Reinaldo, Wully, Lucas, / Sidi, col." [white label, printed in black] (2 o' dissected, DZUP). "Brasil, Pará, Uruará / Cacau [cocoa plantations, Theobroma cacao L.], II-III-2015, / Inverno [winter season], Serrapilheira [Forest litter] / Reinaldo, Wully, Lucas, col." [white label, printed in black] (3 o', DZUP). "Brasil, Pará, Uruará / Mata [Native Vegetation], VI-2015, / Intermediário [collection information], / Serrapilheira [Forest litter] / Reinaldo, Wully, Lucas, / Sidi, col." [white label, printed in black] (1 \&, DZUP). "Brasil, Pará, Uruará
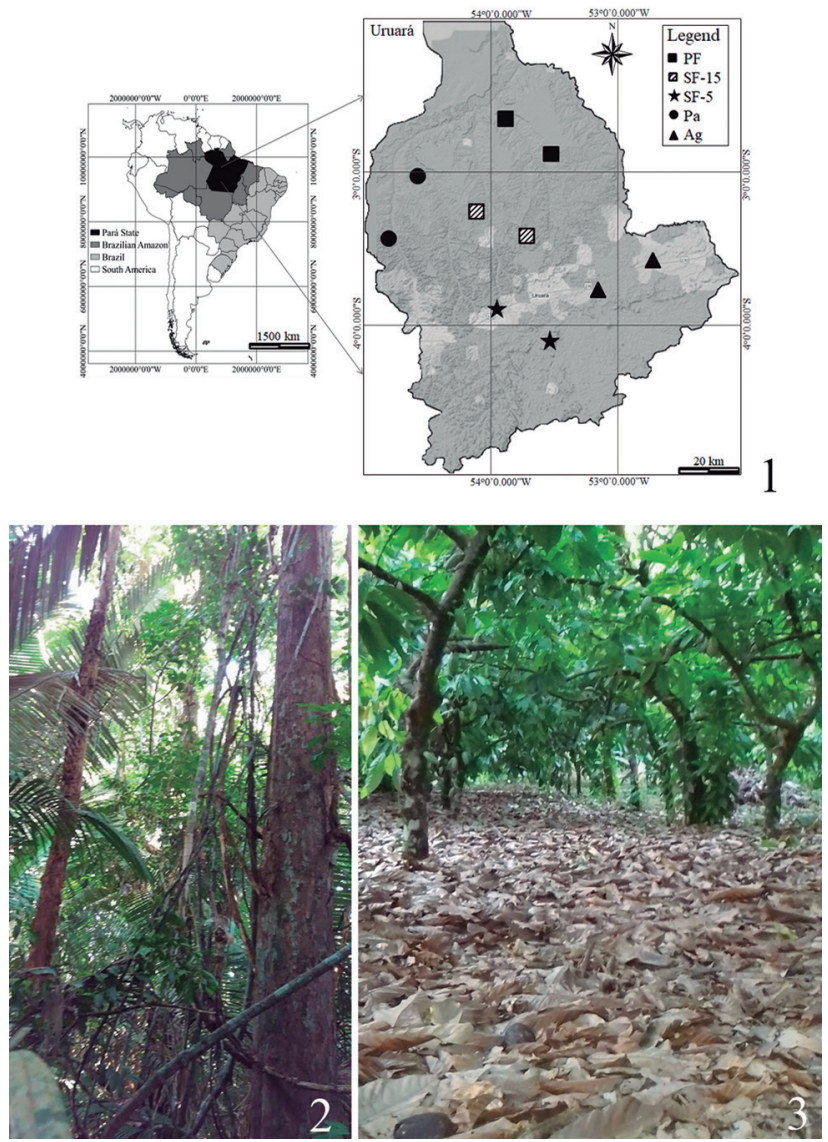

Figures 1-3. (1) Municipality of Uruará, state of Pará, northern Brazil (PF, primary forest; SF-15, secondary forest with 15 years of regeneration; SF-5, secondary forest with five years of regeneration; $\mathrm{Ag}=$ agriculture; $\mathrm{Pa}=$ pasture for extensive livestock). (2) Detail of primary forest. (3) Detail of agriculture (cocoa plantations, Theobroma cacao L.). 
/ Mata [Native Vegetation], IX-X-2015, / Verão [summer season], Serrapilheira [Forest litter] / Reinaldo, Wully, Lucas, / Sidi, col." [white label, printed in black] (1 ơ, 2 \%, DZUP). "Brasil, Pará, Uruará / Mata [Native Vegetation], IIIII-2015, / Inverno [winter season], Serrapilheira [Forest litter] / Reinaldo, Wully, Idielson, / col." [white label, printed in black] (1 o', DZUP).

Diagnosis and description: See Irmler (2017: 34-35).

Remarks: The specimens from Pará, identified as Diochus santacatarinae, have similar aedeagus (mainly parameres) and spermatheca as those illustrated by Irmler (2017) (Figs. 7-9). However, the males have the sternum VIII with posterior margin emarginate at the middle, whereas the females have the sternum VIII with posterior margin broad, curved and slightly acute at the middle (Figs. 18-19). The male and female sternum VIII were not described by Irmler (2017). In the same way, Smetana (1982) and Zhou \& Zhou (2016) have not discussed the male and female sternum VIII for Diochus. Smetana (1977) illustrated the emarginate posterior margin of sternum VIII of the male of $D$. nanus Erichson, but did not discuss it for the females. Naomi (1989) commented about the sexual dimorphism on sternum VIII in many rove beetle groups, but not explicitly for Diochus. Chatzimanolis \& Engel (2011) described the fossil species D. electrus based on a female in which the sternum VIII shows no secondary sexual structures (maybe with posterior margin rounded or at least not emarginate). We believe that the sexual dimorphism on sternum VIII in Diochus is common and might also occur in other species of the genus.

The specimens of $D$. santacatarinae studied here were found in forest litter of cocoa plantations (Theobroma ca-

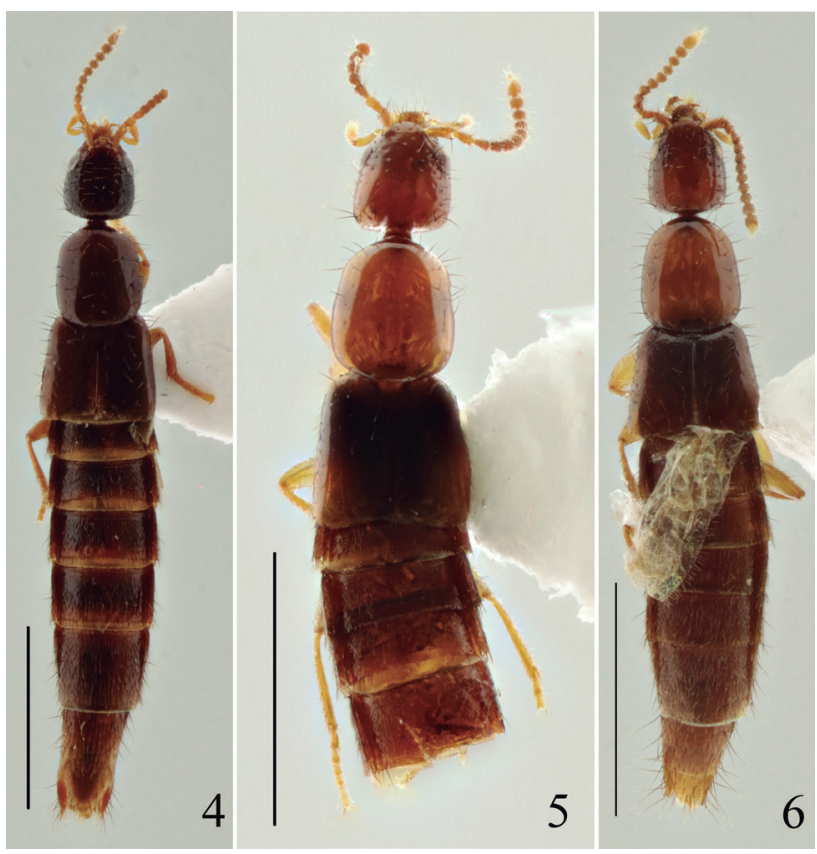

Figures 4-6. Habitus (dorsal). (4) Diochus santacatarinae Irmler; (5) D. parvulus Kraatz; (6) D. cleidecostae Caron \& Navarro sp. nov., paratype (female). Scale bars: $1 \mathrm{~mm}$. cao Linnaues) (Fig. 3), secondary vegetation (five and 15 years of regeneration) and native vegetation (Fig. 2).

Diochus santacatarinae was previously known from French Guiana, Ecuador, Peru and southern Brazil (Santa Catarina state). The species is recorded for the first time from Pará state, in northern Brazil.

\section{Diochus parvulus Kraatz, 1860}

(Figs. 5, 10-14)

Diochus parvulus Kraatz, 1860: 27 (original description, type locality: "Bahia"); Bernhauer \& Schubert, 1914: 319 (catalogue, as valid species); Blackwelder, 1943: 456 (mention as synonym of $D$. nanus Erichson); Blackwelder, 1944: 143 (catalogue, as synonym of D. nanus Erichson); Herman, 2001: 2447 (catalogue, as synonym of D. nanus Erichson); Irmler, 2017: 39 (re-description, as valid species).

Holotype (not seen) deposited in Senckenberg Deutsches Entomologisches Institut, Müncheberg, Germany (SDEI) (Irmler, 2017).

Material examined: "Brasil, Pará, Uruará / Mata [Native vegetation], VI-2015, / Intermediário [collection information], / Pitfall banana / Reinaldo, Wully, Lucas, / Sidi, col." [white label, printed in black] (1 $\sigma^{\prime \prime}$, dissected, DZUP). "Brasil, Pará, Uruará / Pastagem [Pasture for extensive livestock], VI-2015, / Intermediário [collection information], / Serrapilheira [Forest litter] / Reinaldo, Wully, Idielson, / col." [white label, printed in black] (1 $\%$, dissected, no head, DZUP).

Diagnosis and description: See Irmler (2017: 39-41).

Remarks: The specimens from Pará, identified as Diochus parvulus, have similar aedeagus (mainly parameres) and spermatheca as those illustrated by Irmler (2017) (Figs. 10-14). However, similarly to Diochus santacatarinae, the male of $D$. parvulus has the sternum VIII with posterior margin emarginate at the middle, whereas the female has the sternum VIII with posterior margin broad curved and slightly acute at the middle.

The specimens of $D$. parvulus were collected using the winkler method in forest litter of pasture for extensive livestock and using pitfalls baited with banana in native vegetation (Fig. 2).

Diochus parvulus was previously known from Venezuela, Ecuador, Paraguay, Argentina and Brazil (from the states of Amazonas, Mato Grosso, Rio de Janeiro and Santa Catarina). The species is recorded for the first time from the state of Pará.

\section{Diochus cleidecostae Caron \& Navarro sp. nov. (Figs. 6, 15-17, 20-22)}

Type material: HOLOTYPE (o", DZUP): "Brasil, Pará, Uruará / Cap5 [secondary vegetation with five years of 
regeneration], VI-2015, / Intermediário [collection information], Serrapilheira [Forest litter] / Reinaldo, Wully, Sidi, col." [white label, printed in black]; "HOLOTYPE / Diochus cleidecostae Caron \& Navarro / det. E. Caron, 2019" [red label, printed in black]. PARATYPES: the first label as the holotype; "PARATYPE / Diochus cleidecostae Caron \& Navarro / det. E. Caron, 2019" [yellow label, printed in black] (2 o", 2 , DZUP and 1 o', 1 \%, MZSP). “Brasil, Pará, Uruará / Mata [native vegetation], IX-X-2015, / Verão [summer season], Pitfall-carne [fresh meat] / Reinaldo, Wully, Lucas, / Sidi, col." [white label, printed in black]; "PARATYPE / Diochus cleidecostae Caron \& Navarro / det. E. Caron, 2019" [yellow label, printed in black] (1, DZUP).
Diagnosis: Within Diochus nanus-group, D. cleidecostae Caron \& Navarro sp. nov. differs from D. apicipennis Cameron, D. nanus and D. perplexus Cameron by having an aedeagus with clearing trifurcate apex of parameres (parameres bifurcate at the apex in D. apicipennis, $D$. nanus and $D$. perplexus), and differs from $D$. parvulus by having three apical long setae of parameres distributed on ventral and dorsal lobes, and without long setae on medial lobe (one of three apical long setae on medial lobe in D. parvulus).

Description: Male: Maximum body length: $3.00 \mathrm{~mm}$; maximum elytral width: $0.56 \mathrm{~mm}$. Body light brown to

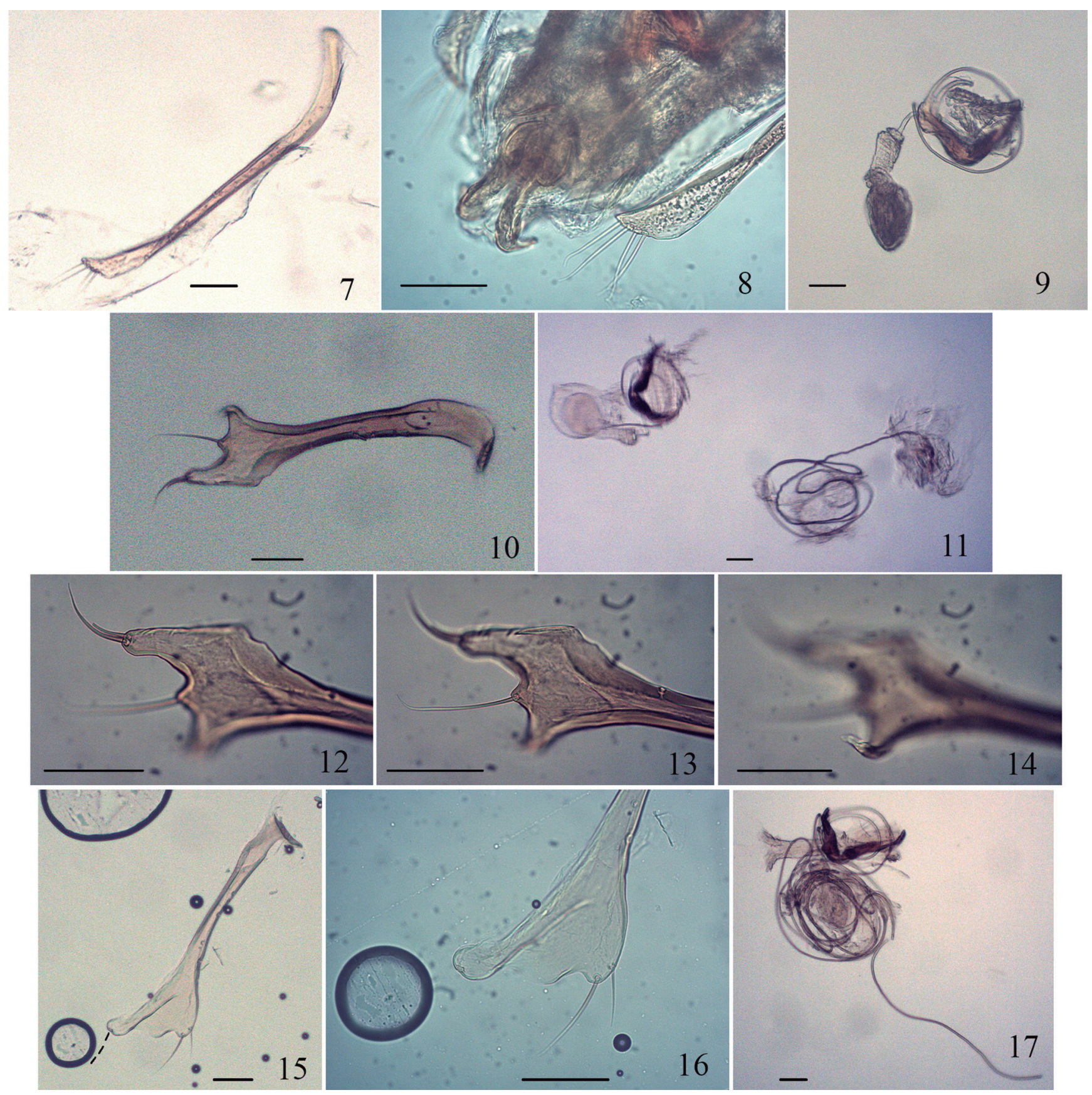

Figures 7-17. Dissected parts, microscope photographs. (7-9) Diochus santacatarinae Irmler: (7) Paramere; (8) Apex of aedeagus; (9) Spermatheca; (10-14) D. parvulus Kraatz: (10) Paramere; (11) Spermatheca; (12) Apex of paramere, focusing on ventral lobe; (13) Apex of paramere, focusing on median lobe; (14) Apex of paramere, focusing on dorsal lobe. (15-17) D. cleidecostae Caron \& Navarro sp. nov.: (15) Paramere (dashed line indicates lost seta); (16) Apex of paramere; (17) Spermatheca. Scale bars: $0.06 \mathrm{~mm}$. 

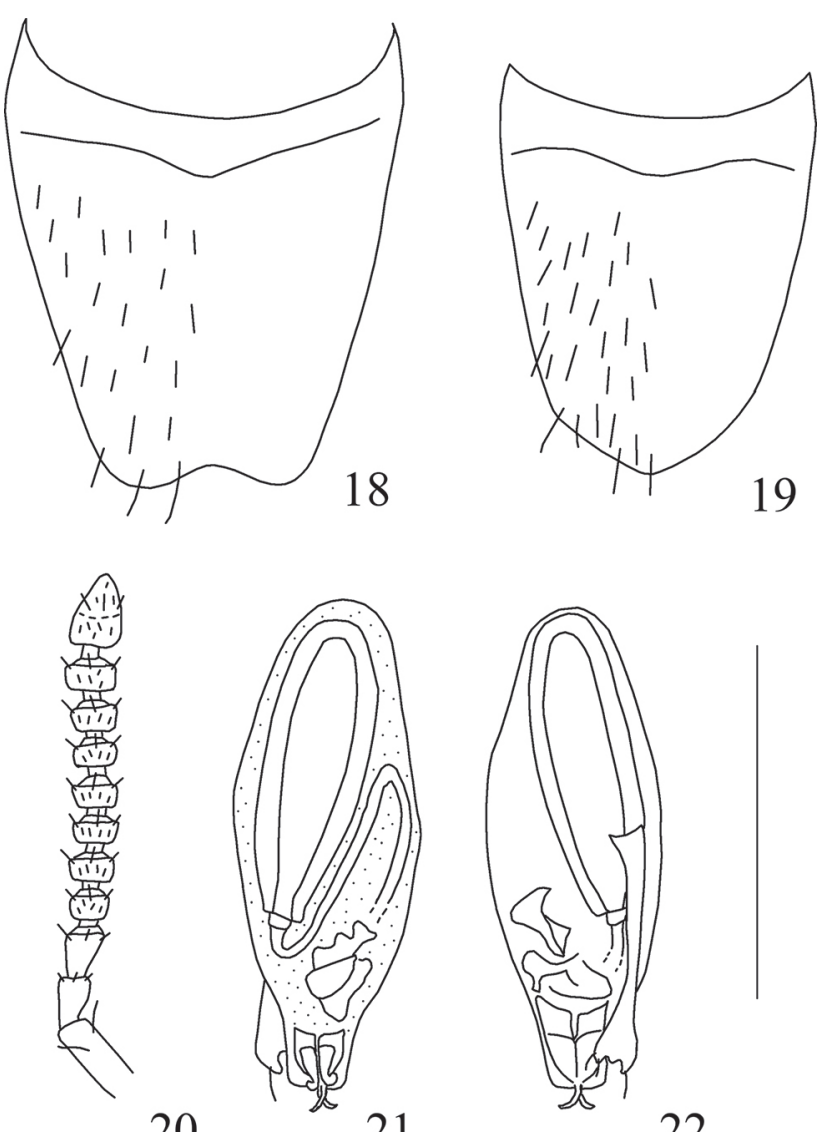

20

21

22

Figures 18-22. Dissected parts, drawings. (18-19) D. santacatarinae Irmler: (18) Sternite 8 of male, ventral; (19) Sternite 8 of female, ventral; (2022) D. cleidecostae Caron \& Navarro sp. nov.: (20) antenna; (21) Aedeagus, dorsal; (22) Aedeagus, ventral. Scale bars: $0.5 \mathrm{~mm}$.

brown, elytra darker (Fig. 6); appendices yellowish, antennae slightly darker than other appendices; antennomere 11 with apical half lighter than basal half. Head: Head longer than wide, length $0.40 \mathrm{~mm}$, width $0.34 \mathrm{~mm}$; eyes prominent, $0.11 \mathrm{~mm}$ long; temples twice as long as eyes; $\mathrm{EL}: \mathrm{HL}=0.28$; temples parallel, $\mathrm{PW}: \mathrm{EW}=1.18$; posterior angles rounded. Dorsal surface of head slightly microsculptured, vertex impunctate midline, convergent row of four punctures from anterior edge of eyes to middle of vertex, postocular area and at posterior marginal area more setiferous punctures. Antennae slightly longer than head; antennomere 1 nearly as long as 2-3 combined; 2 as long as 3; 3 one-fourth longer than 4; 4-10 wider than long, with same length, slightly increasing in width; 10 around twice wider than long; 11 nearly wider than 10 and length of 9-10 combined (Fig. 20). Gular plate with sides divergent towards anterior margin. Thorax: Pronotum longer than wide, $0.50 \mathrm{~mm}$ long and
$0.44 \mathrm{~mm}$ wide; anterior and posterior angles rounded; anterior third strongly convergent. Dorsal surface of pronotum glossy; adjacent to wide impunctate midline with row of three punctures; interstice between anterior pair twice as wide as interstices between posterior pairs; four additional punctures laterad; several setiferous punctures along lateral margin. Elytra wider than long, $0.44 \mathrm{~mm}$ long, $0.56 \mathrm{~mm}$ wide; sides divergent towards posterior margin; posterior margin slightly emarginate. Elytra glossy, setiferous punctures in irregular rows; first row of five punctures adjacent to suture line; two additional rows laterad; interstice between two rows on disc much closer than between row at suture and first row on disc. Hind wings developed. Tarsal formula 5-5-5; fore tarsomeres 1-4 strongly dilated; mid and hind tarsomeres 1-4 clearing decreasing in length; mid and hind tarsomeres 5 nearly the length of 3-4 combined. Abdomen: Abdominal segments III-VI with sides subparallel, VII-VIII clearing convergent to posterior margin; densely pubescent. Posterior margin of tergum VIII truncate at middle two-fourths. Posterior margin of sternum VIII emarginate at the middle. Tergum $X$ separating tergum IX in two equal parts. Tergum IX with elongate ventral struts. Posterior margin of sternum IX emarginate at the middle. Posterior margin of tergum $X$ rounded. Aedeagus twice as long as wide (Figs. 21-22); seminal vesical of endophallus diagonal, 0.62 times as long as central lobe; basal inner duct shortly looped; complex of sclerotised apical forceps; central lobe with acute and crossed apical hooks. Parameres well-developed, each widened and forming large plate at the apex, trifurcate; three apical long setae, two on ventral lobe and one on dorsal lobe (Figs. 15-16).

Female: Similar to male, except for posterior margin of sternum VIII broadly rounded; tergum IX without ventral struts; sternum IX consisting of pair of hemisternites; spermatheca small with capsule of subspherical shape; bursa copulatrix in lateral position to coiled approximately circular duct (Fig. 17).

Biological notes: The specimens of $D$. cleidecostae sp. nov. were found in forest litter secondary vegetation (five years of regeneration) and native vegetation (Figs. 1, 2).

Etymology: The specific name "cleidecostae" is formed from a personal name and treated as noun in the genitive case (ICZN, 1999, art. 31.1). The specific name honors the Brazilian coleopterologist Dr Cleide Costa, from MZSP and specialist of immature insects.

\section{Key to males of the Neotropical species of Diochus belonging to the $D$. nanus-group (Adapted from Irmler, 2017, through the couplets 27 to 29)}

1. Eyes small, EL : HL ratio 0.21 (Irmler, 2017: fig. 45E); parameres broadly curved at the apex (Irmler, 2017: fig. 37B). Guadeloupe and Saint Vincent

D. apicipennis Cameron

— Eyes larger, EL : HL ratio 0.27-0.28 (Figs. 5-6); parameres bifurcate or trifurcate at the apex

2. Parameres trifurcate at the apex, with dorsal, medial and ventral lobes. 
- Parameres clearing bifurcate at the apex, with dorsal and ventral lobes

3. Body yellow with anterior half of elytra black (Fig. 5); trifurcate parameres with one apical long setae on medial lobe (Figs. 10, 12-14). Venezuela, Ecuador, Brazil, Paraguay and Argentina

D. parvulus Kraatz

- Body light brown to brown, anterior half of elytra not distinctly darker than posterior half (Fig. 6); trifurcate parameres without apical setae on medial lobe (Figs. 15-16). Brazil. D. cleidecostae Caron \& Navarro sp. nov.

4. Apical incision of parameres short and acute (Irmler, 2017: fig. 34B), pronotum polished without remains of microsculpture. Barbados, Cuba, Grenada, Guadeloupe, Dominican Republic, Puerto Rico, British Virgin Islands, Trinidad, Guatemala, Honduras, Nicaragua, Costa Rica, Panama, Venezuela, Colombia, Guyana, French Guiana, Ecuador, Peru D. perplexus Cameron

- Apical incision of parameres deep and obtuse (Irmler 2017: fig. 35B), pronotum shiny with remains of microsculpture on anterior half. Costa Rica, Panama, Colombia, Suriname and Saint Thomas. D. nanus Erichson

\section{ACKNOWLEDGMENTS}

This research was supported by the Brazilian National Counsel of Technological and Scientific Development (CNPq), under 479960/2010-0 and 476361/2013-3. We are thankful to Ana Buss for the photographs of habitus, the editor and anonymous reviewers for valuable suggestions on the manuscript and J. Smith for English corrections.

\section{REFERENCES}

Bernhauer, M. \& Schubert, K. 1914. Staphylinidae IV. In: Schenkling, S. (Ed.). Coleopterorum Catalogus. Berlin, Junk. p. 289-408.

Blackwelder, R.E. 1943. Monograph of the West Indian beetles of the family Staphylinidae. United States National Museum Bulletin, 1-658.

Blackwelder, R.E. 1944. Checklist of the coleopterous insects of Mexico, Central America, the West Indies, and South America. Part 1. Bulletin United States National Museum, 185: xii + 1-188.

Cai, C.-Y.; Wang, Y.-L.; Liang, L.; Yin, Z-W.; Thayer, M.K.; Newton, A.F. \& Zhou, Y-L. 2019. Congruence of morphological and molecular phylogenies of the rove beetle subfamily Staphylininae (Coleoptera: Staphylinidae). Scientific Reports, 9 (15137): 1-11. D0I

Cajaiba, R.L.: Périco, E.; Caron, E.; Dalzochio, M.S.; Silva, W.B. \& Santo, M. 2017. Are disturbance gradients in neotropical ecosystems detected using rove beetles? A case study in the Brazilian Amazon. Forest Ecology and Management, 405: 319-327. D0I

Chatzimanolis, S. \& Engel, M. 2011. A new species of Diochus from Baltic amber (Coleoptera, Staphylinidae, Diochini). Zookeys, 138: 65-73. D01

Herman, L.H. 2001. Catalog of the Staphylinidae (Insecta: Coleoptera) 1758 to the end of the second millenium, parts I-VII. Bulletin of the American Museum of Natural History, 167: 1-4218.
International Commission on Zoological Nomenclature (ICZN). 1999. International code of zoological nomenclature. 4.ed. London, The International Trust for Zoological Nomenclature. xxix + 306p.

Irmler, U. 2017. A review of the Neotropical genus Diochus Erichson, 1840 (Coleoptera: Staphylinidae: Staphylininae). Contributions to Entomology: Beiträge zur Entomologie, 67(1): 1-62. D01

Kraatz, G. 1860. Ueber die Gattung Diochus Er. Wiener Entomologische Monatschrift, 4: 25-28.

Naomi, S.-I. 1989. Comparative morphology of the Staphylinidae and the allied groups (Coleoptera, Staphylinoidea). X. Eighth to $10^{\text {th }}$ segments of abdomen. Japanese Journal of Entomology, 57: 720-733.

Newton, A.F. 2019. StaphBase: Staphyliniformia world catalog database (version Nov 2018). In: Roskov, Y.; Ower, G.; Orrell, T.; Nicolson, D.; Bailly, N.; Kirk, P.M.; Bourgoin, T.; DeWalt, R.E.; Decock, W.; Nieukerken, E. van; Zarucchi, J. \& Penev, L. (Eds.). Species 2000 \& ITIS Catalogue of Life, 2019 Annual Checklist. Species 2000. Leiden, Naturalis. (Digital resource at www.catalogueoflife.org/annual-checklist/2019)

Smetana, A. 1977. Lectotype designations and taxonomic remarks on some xantholinine genera and species from Central and South America (Coleoptera: Staphylinidae). The Coleopterists Bulletin, 31: 347-362.

Smetana, A. 1982. Revision of the subfamily Xantholininae of America north of Mexico (Coleoptera: Staphylinidae). Memoirs of the Entomological Society of Canada, 12: 1-389.

Zhou, Y.-L. \& Zhou, H.-Z. 2016. Taxonomy of the genus Diochus Erichson, 1839 (Coleoptera: Staphylinidae, Staphylininae, Diochini) in China with descriptions of four new species. Zootaxa, 4127: 1-30.

Zyla, D. \& Solodovnikov, A. 2019. Multilocus phylogeny defines a new classification of Staphylininae (Coleoptera, Staphylinidae), a rove beetle group with high lineage diversity. Systematic Entomology, 45(1): 114-127. 